\title{
Rendimiento y calidad de forraje del pasto ovillo (Dactylis glomerata L.) al variar la frecuencia e intensidad de pastoreo
}

\section{Herbage yield and quality of orchard grass (Dactylis glomerata L.), under different grazing frequencies and intensities}

\author{
J orge Armando Villareal Gonzáleza, Alfonso Hernández Garaya, Pedro Arturo Martínez \\ Hernández ${ }^{b}$, J uan de Dios Guerrero Rodríguezc, Ma. Eugenia Velasco Zebadúad
}

\begin{abstract}
RESUMEN
El objetivo fue determinar el rendimiento y calidad del pasto ovillo (Dactylis glomerata L.), al variar la frecuencia e intensidad de pastoreo. Se evaluaron tres frecuencias $(2,3$ y 4 semanas en primavera y verano y 4,5 y 6 semanas durante otoño) y dos intensidades de pastoreo (severa: 3 a $5 \mathrm{~cm}$ y ligera: 6 a $8 \mathrm{~cm}$ de altura de forraje residual). Se evaluó el rendimiento de forraje, tasa de acumulación neta de forraje (TANF), composición morfológica y calidad del forraje. El mayor rendimiento acumulado y TANF se presentaron con pastoreo severo cada 4 y 6 semanas y en ambas intensidades cada 3 y 5 semanas. El mayor rendimiento estacional $(7,844 ; 7,699 ; 7114 \mathrm{~kg}$ MS ha-1) se presentó en verano en las mismas frecuencias e intensidades de pastoreo, respectivamente $(P<0.05)$. Durante primavera no se observaron diferencias en rendimiento y TANF entre frecuencias de pastoreo. En otoño la frecuencia de 5 semanas superó a la de $4(P<0.05)$, pero no diferente a la de 6 semanas. En todas las estaciones del año la intensidad de pastoreo severo superó a la ligera, siendo diferentes en primavera y verano $(P<0.05)$. En general, el contenido de proteína total y digestibilidad in vitro de la materia seca tendieron a disminuir conforme aumentó el intervalo de pastoreo, siendo en promedio de 20 y $65 \%$, respectivamente. Se concluye que para obtener el mayor rendimiento y calidad de forraje, los pastoreos deben realizarse cada 4 semanas durante primavera-verano y cada 5 semanas en otoño, a una intensidad severa.
\end{abstract}

PALABRAS CLAVE: Dactylis glomerata L., Pastoreo, Rendimiento, Tasa acumulación neta, Calidad nutritiva.

\begin{abstract}
The aim of this experiment was to study the performance of Orchard grass (Dactylis glomerata L.) based on herbage yield and quality under different grazing management. Three frequencies (2, 3 and 4 wk in spring and summer and 4, 5 and 6 wk in fall) and two grazing intensities (hard: 3 to $5 \mathrm{~cm}$ and lax: 6 to $8 \mathrm{~cm}$ of residual sward height), in a randomized block design with three replicates, distributed in a $2 \times 3$ factorial arrangement. Cumulative herbage yield (CHY), net herbage accumulation rate (NHAR), morphological composition and herbage quality were evaluated. The highest CHY and average NHAR were recorded with hard grazing every 4 and 6 wk. The highest seasonal herbage

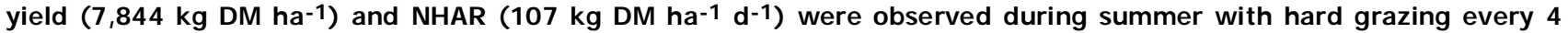
wk $(P<0.05)$. There were not statistical differences in herbage yield and NHAR during spring between grazing frequencies. In fall, 5 wk grazing frequency was higher than 4 wk $(P<0.05)$, but it was similar to 6 wk $(P>0.05)$. Across all seasons, hard grazing gave higher forage yield than lax grazing, being different in spring and summer $(P<0.05)$. In overall, total protein and in vitro dry matter digestibility tended to decrease as grazing interval increased, being on average 20 and $65 \%$, respectively. It was concluded that to obtain the highest herbage yield and quality, orchard grass must be grazed hard every 4 wk in spring-summer and every 5 wk in fall.
\end{abstract}

KEY WORDS: Dactylis glomerata L., Grazing, Yield, Net accumulation rate, Nutritive value.

Recibido el 24 de abril de 2012. Aceptado el 2 de agosto de 2012.

Ganadería. Campus Montecillo, Colegio de Postgraduados. 56230. Montecillo Estado de México. México. hernana@colpos.mx. Correspondencia al segundo autor.

Departamento de Zootecnia, Universidad Autónoma Chapingo. México.

Campus Puebla, Colegio de Postgraduados. México.

d Facultad de Veterinaria. Universidad Autónoma de Chiapas. México. 
La producción animal a base de forrajes es una forma efectiva, económica y eficiente de producir alimento de calidad en comparación con la explotación de animales confinados o consumiendo concentrados y dietas altas en granos. El pastoreo es considerado como la forma "natural" de producir alimentos de origen animal, razón por la cual, es una opción bastante estudiada como alternativa de explotación económica de la tierra. Para mejorar la rentabilidad de los sistemas pastoriles se ha señalado debe incrementarse la producción animal por unidad de área mediante el aumento en la productividad del componente forrajero(1).

El pasto ovillo (Dactylis glomerata L.), por su alto rendimiento y calidad nutritiva(2) es una de las plantas forrajeras más cultivadas mundialmente. En México, junto con el ballico perenne (Lolium perenne L.), son las gramíneas más utilizadas en las zonas templadas, áridas y semiáridas, para la producción de leche, y en menor escala, en la engorda de ganado bovino y ovino $(2,3)$. Para lograr una adecuada utilización del pasto ovillo es importante conocer el momento oportuno de defoliación desde el punto de vista rendimiento, calidad y persistencia de la pradera(4). La frecuencia e intensidad de pastoreo son los componentes principales que determinan la eficiencia productiva de una especie, ya que tienen influencia directa sobre la cantidad y calidad del forraje producido(5). El intervalo entre defoliaciones es generalmente más importante que la severidad para determinar el efecto sobre la velocidad de rebrote(6). En pasto ovillo se ha reportado que las defoliaciones más frecuentes resultan en una reducción de los carbohidratos no estructurales (CNE), por lo que se reducen los pesos de hoja, tallo y raíz y se retrasa el rebrote ${ }^{(7)}$. Además los CNE durante el proceso de rebrote fueron asignados prioritariamente hacia crecimiento de hoja, luego el de raíz y por último a nuevos tallos, similar a lo descrito para ballico perenne(8) y festuca alta(9).

Conocer el efecto del intervalo e intensidad de pastoreo sobre la productividad de la pradera,
Based on grazing, animal production is an effective, economic, and efficient way of producing quality food versus production of confined animals consuming concentrates and high grain diets. Grazing is considered the "natural" way of producing food from animal origin, reason why, it's a well studied option for an alternative use of land. To improve the profitability of grazing systems, animal production per unit area should be enhanced by increasing the productivity of herbage mass $(1)$.

Orchard grass (Dactylis glomerata L.), for its high yield and nutritional value(2) is one of the most cultivated herbage plants worldwide. In Mexico, along with the perennial ryegrass (Lolium perenne L.), are most commonly used in the temperate, arid and semi-arid areas for milk production, and on a smaller scale for cattle and sheep fattening(2,3). To achieve a proper use of the orchard grass is important to know the right time of defoliation from the herbage yield point of view, quality and persistence of the sward(4). The frequency and intensity of grazing are the main components that determine the production efficiency of a specie, since they have a direct influence on the quantity and quality of the produced herbage ${ }^{(5)}$. The interval between defoliations is usually more important than the severity to determine the effect on the speed of regrowth ${ }^{(6)}$. In orchard grass the most frequent defoliations result in a reduction of nonstructural carbohydrates (NEC), thereby reducing the weights of leaf and stem, and sward regrowth is delayed(7). In addition, NEC during the regrowth process were primarily assigned to leaf growth, then to root and finally to new stems, similar to that described for perennial ryegrass $(8)$ and fescue ${ }^{(9)}$.

Knowing the effect of the grazing frequency and intensity on the grassland productivity, allows adequate management, so the persistence and regrowth speed of herbage species are not harm and they are properly used from the yield and herbage quality 
permite realizar un manejo apropiado, de modo que no se perjudique la persistencia y velocidad de rebrote de las especies forrajeras y con ello, utilizarlas de manera oportuna desde el punto de vista de rendimiento y calidad de forraje $(10,11)$. Se han realizado diversos estudios para describir la respuesta del pasto ovillo al manejo de la defoliación en términos de rendimiento anual y su distribución estacional, análisis de crecimiento, competencia entre la parte aérea y radical, valor nutritivo y respuestas fisiológicas en praderas puras y asociadas con alfalfa y otros pastos $(12,13,14)$; sin embargo, en México, existen pocos estudios sobre el impacto de variar la frecuencia del pastoreo según la estación del año en conjunto con variación en la intensidad del pastoreo. El presente estudio tuvo como objetivo evaluar, en términos de rendimiento y calidad de forraje, el comportamiento productivo del pasto ovillo (Dactylis glomerata L.), al variar estacionalmente la frecuencia e intensidad de pastoreo.

El estudio se realizó de febrero a diciembre de 2007, y abarcó las estaciones de primavera, verano y otoño, en una pradera de pasto ovillo (Dactylis glomerata L.) variedad Potomac, con cuatro años de establecida. El experimento se localizó en el Campo Experimental del Colegio de Posgraduados en Montecillo, Texcoco, Estado de México a $2,240 \mathrm{msnm}$ y a $19^{\circ} 31^{\prime} \mathrm{N}$ y $98^{\circ}$ 53' O, el clima es templado subhúmedo, con lluvias en verano, precipitación media anual de $645 \mathrm{~mm}$ y temperatura media anual de $15 \stackrel{\circ}{ } \mathrm{C}$; la temperatura promedio del mes más frío se registró en enero (11.6 ㄷ) y la más alta (18.4 ${ }^{\circ} \mathrm{C}$ ) en mayo(15). El suelo del área presenta una textura migajón arenoso, ligeramente alcalino ( $\mathrm{pH}$ 7.8), con $2.4 \%$ de materia orgánica(16).

Antes de iniciar el estudio, la pradera fue defoliada a $8 \mathrm{~cm}$ de altura de forraje residual cada dos semanas. El área experimental total fue $5,000 \mathrm{~m}^{2}$, para el estudio se usaron 1,800 $\mathrm{m}^{2}$ (18 parcelas de $100 \mathrm{~m}^{2}$ cada una), en toda esta área el ovillo componía más del $80 \%$ de la composición botánica. Las parcelas se viewpoint $(10,11)$. Various studies have been conducted to describe the response of the orchard grass to defoliation management in terms of annual herbage yield and their seasonal distribution, growth, competition between the aerial and radical parts, nutritive value and physiological responses in grasslands, alone and associated with alfalfa and other grasses $(12,13,14)$. However, in Mexico, there are few studies on the impact of varying the frequency of the grazing, according to the season of the year as a whole with variation in the grazing intensity. The objective of this study was to assess, in terms of herbage yield and quality of herbage, the productive performance of the orchard grass (Dactylis glomerata L.), seasonally changing the grazing frequency and intensity.

The study was carried out from February to December 2007, and covered the seasons of spring, summer, and autumn, in a sward of orchard grass, Potomac variety, established 4 yr ago. The experiment was located at the Experimental Station of the "Colegio de Postgraduados" in Montecillo, Texcoco, State of Mexico to $2,240 \mathrm{~m}$ asl and $19^{\circ} 3^{\prime} \mathrm{N}$ and $98^{\circ}$ $53^{\prime} \mathrm{W}$. The climate is temperate sub humid, with summer rains, mean annual rainfall of 645 $\mathrm{mm}$ and mean annual temperature of $15^{\circ} \mathrm{C}$; the average temperature of the coldest month was recorded in January $\left(7.2^{\circ} \mathrm{C}\right)$ and the highest $\left(18.4{ }^{\circ} \mathrm{C}\right.$ ) on May $(15)$. The soil presents a granular sandy texture, slightly alkaline ( $\mathrm{pH} 7.8)$, with $2.4 \%$ organic matter(16).

Before starting the study, the sward was defoliated to $8 \mathrm{~cm}$ in residual sward height every $2 \mathrm{wk}$. The total experimental area was $5,000 \mathrm{~m}^{2}$, and $1,800 \mathrm{~m}^{2}$ (18 plots of $100 \mathrm{~m}^{2}$ each) were used for the study; throughout this area the orchard composed more than $80 \%$ of the botanical composition. Plots were fertilized with $40 \mathrm{~kg} \mathrm{ha}-1 \mathrm{~N}$, at the beginning of the study, and irrigation were provided by spraying every $2 \mathrm{wk}$ in the dry season. Treatments consisted of two intensities (3-5 and 6-8 cm residual sward height) and three grazing intervals $(2,3$, and 4 wk during spring/summer, 
fertilizaron con $40 \mathrm{~kg} \mathrm{ha}^{-1}$ de $\mathrm{N}$, al inicio del estudio, y en la época seca se proporcionaron riegos por aspersión cada dos semanas. Los tratamientos consistieron en dos intensidades ( 3 a 5 y 6 a $8 \mathrm{~cm}$ de altura del forraje residual) y tres intervalos de pastoreo $(2,3$ y 4 semanas durante primavera-verano, y 4, 5 y 6 semanas en otoño), y se distribuyeron en un diseño de bloques al azar con tres repeticiones, en un arreglo factorial $2 \times 3$. Se utilizó el pastoreo rotacional con una carga que varió entre 5 y 12 ovinos por parcela, según el tratamiento y estación del año, con fin de llegar a la intensidad de pastoreo evaluada en un máximo de $8 \mathrm{~h}$.

Para determinar el rendimiento de forraje, un día antes del pastoreo, se cortaron aleatoriamente dos cuadros de $0.25 \mathrm{~m}^{2}$ por repetición, de acuerdo a la intensidad correspondiente. El material cosechado se pesó en verde, se lavó, se depositó en bolsas etiquetadas y se secó en una estufa de circulación de aire forzado, a $55{ }^{\circ} \mathrm{C}$ por $48 \mathrm{~h}$ y se pesó. Posteriormente, la parcela se defolió con ovinos a la intensidad establecida. La acumulación estacional y total de forraje en cada tratamiento, se obtuvo al sumar el forraje cosechado en los pastoreos, correspondientes a los meses de cada estación y en todos los meses que duró el estudio.

La tasa de acumulación neta de forraje (TANF) se calculó dividiendo la cantidad de forraje cosechado antes de cada pastoreo, entre el número de días transcurridos entre dos pastoreos.

De las muestras para determinar rendimiento de forraje se obtuvieron $200 \mathrm{~g}$ aproximadamente que se separaron manualmente en los componentes morfológicos (hoja, tallo y pseudo tallo, material muerto e inflorescencia). Cada componente se secó en estufa de circulación de aire forzado a $55{ }^{\circ} \mathrm{C}$ por $72 \mathrm{~h}$ y posteriormente pesado para calcular el aporte en porcentaje de cada uno de ellos al rendimiento de forraje.

A mediados de cada estación se obtuvieron muestras de pasto ovillo de los diferentes and 4, 5 and 6 wk in autumn). Treatments were distributed in a random blocks design with three replications, in a $2 \times 3$ factorial arrangement. Rotational grazing with a stocking rate that varied between 5 and 12 sheep per plot, according to treatment and season of the year, with the purpose to reach the grazing intensity evaluated at the maximum of $8 \mathrm{~h}$. To determine herbage yield, a day before the grazing, randomly two $0.25 \mathrm{~m}^{2}$ squares per repetition were cut, according to the corresponding intensity. Harvested material was weighed green, washed, was kept in labeled bags and dried in a forced air circulation stove, at $55{ }^{\circ} \mathrm{C}$ for $48 \mathrm{~h}$, and weighed. Subsequently, all plots were grazed with sheep at the set intensity. The total and seasonal herbage accumulation in each treatment, was obtained by adding herbage harvested in the grazing, corresponding to the months of each season and across the months of the study.

The net herbage accumulation rate (NHAR) was calculated by dividing the amount of harvested herbage before each grazing, by the number of days between two grazing periods.

To determining botanical and morphological composition, from the harvested herbage samples used for determining herbage yield, a $200 \mathrm{~g}$ subsample was taken and separated manually in orchard grass, other grasses and weeds. Orchard grass was also separated in the morphological components (leaf, stem and pseudo stem, dead material and inflorescence). Each component was dried in an air circulation forced oven at $55^{\circ} \mathrm{C}$ for $72 \mathrm{~h}$. Then, weighed to calculate the contribution as a percentage of each of them, to herbage yield.

In the middle of each season, grass samples from the different treatments were obtained, collecting herbage simulating grazing animals. These samples were analyzed for total protein(17) and in vitro dry matter digestibility(18).

Temperature of air and rainfall records occurred during the field phase of the study and were obtained from the meteorological station of the 
tratamientos, colectando forraje simulando el pastoreo de los animales; a estas muestras se les determinó proteína total(17) y de digestibilidad in vitro de la materia seca(18).

Los registros de temperatura del aire y precipitación ocurridos durante la fase de campo del estudio se obtuvieron de la estación meteorológica del Colegio de Postgraduados, ubicada a unos metros del área experimental.

Se realizaron análisis de varianza para todas las variables estudiadas. El rendimiento acumulado y estacional y los aportes porcentuales de cada componente, se analizaron independientemente en cada una de las estaciones. El análisis de los datos se efectuó mediante un diseño en bloques completos al azar con un arreglo factorial $2 \times 3$ usando PROC GLM del paquete estadístico SAS(19) y prueba de medias de Tukey, al $5 \%$ de probabilidad.

En la Figura 1, se observa que la máxima temperatura ocurrió en primavera (mayo) y la menor en invierno (enero), la temperatura promedio mensual en el año fue $16.4{ }^{\circ} \mathrm{C}$
Colegio de Postgraduados, located a few meters from the experimental area.

All variables studied were analyzed by variance. Seasonal and cumulative herbage yield and percentage contributions of each component were analyzed independently in each of the seasons. Analysis of the data was carried out using a complete randomized blocks design with a factorial arrangement $2 \times 3$ using the statistical package SAS PROC GLM(19) and mean Tukey test at $5 \%$ of probability.

Figure 1 shows that the maximum temperature occurred in spring (May) and the lowest on winter (January), the monthly average temperature in the year was $16.4{ }^{\circ} \mathrm{C}, 1.4{ }^{\circ} \mathrm{C}$ higher than the historical average(15). The annual rainfall in 2007 was $723 \mathrm{~mm}, 78 \mathrm{~mm}$ above the landmark report. In summer occurred $52 \%$ of annual rainfall, mainly in July and August; in spring the greater precipitation took place in June, with $144 \mathrm{~mm}$.

Regardless of the frequency and intensity of grazing, the total herbage yield had a

Figura 1. Temperatura y precipitación registradas de enero a diciembre de 2007 en el sitio experimental. Montecillo, Estado de México

Figure 1. Temperature and precipitation register from January to December 2007 at the experimental, station, Montecillo, Estado de México

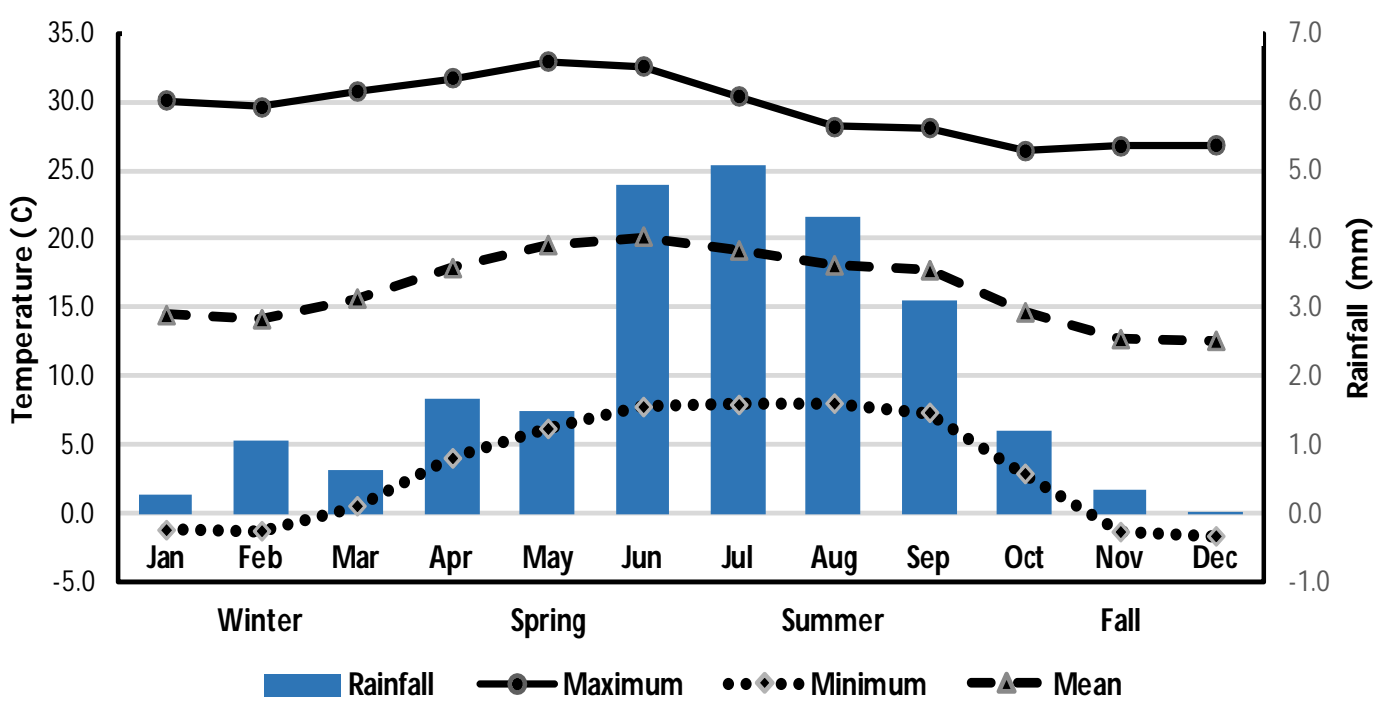


superior en 1.4 ㄷ a la media histórica(15). La precipitación anual en 2007 fue 723 mm, 78 $\mathrm{mm}$ por arriba del reporte histórico. En verano ocurrió $52 \%$ de la precipitación anual, principalmente en julio y agosto; en primavera la mayor precipitación ocurrió en junio con 144 $\mathrm{mm}$.

Independientemente de la frecuencia e intensidad del pastoreo, el rendimiento total de biomasa tuvo una distribución de 40, 31 y $29 \%$ en verano, primavera y otoño, respectivamente (Cuadro 1). Únicamente durante verano la producción total de forraje presentó interacción entre la frecuencia e intensidad de pastoreo $(P<0.05)$. La máxima producción total de forraje considerando las tres estaciones de estudio $\left(21,086 \mathrm{~kg} \mathrm{MS} \mathrm{ha}^{-1}\right)$ se registró con la menor distribution of 40,31 and $29 \%$ in summer, spring and autumn, respectively (Table 1 ). Only during summer, total herbage production presented interaction between frequency and intensity of grazing $(P<0.05)$. The maximum total herbage production considering the three seasons $(21,086 \mathrm{~kg}$ DM ha-1) was recorded with the lowest grazing frequency (4-6 wk in spring-summer and autumn, respectively) in combination with the lowest grazing intensity of 3 and $5 \mathrm{~cm}$ of residual sward height (Table $1)$. Hard grazing surpassed $(P<0.05)$ in herbage yield to the lax to 38,17 and $14 \%$ in spring, summer and fall, respectively. The superiority of the hard grazing in herbage yield found in the present study does not coincide with other studies where hard and frequent grazing tends

Cuadro 1. Rendimiento de forraje estacional y acumulado de pasto ovillo (kg MS ha-1), en respuesta a tres frecuencias y dos intensidades de pastoreo

Table 1. Seasonal herbage yield and accumulated orchard grass (kg DM ha-1) in response to three frequencies and two grazing intensities

\begin{tabular}{|c|c|c|c|c|c|}
\hline \multicolumn{2}{|c|}{ Treatments } & \multicolumn{3}{|c|}{ Season } & \multirow[b]{2}{*}{ Total } \\
\hline Frequency & Intensity & Spring & Summer & Falla & \\
\hline \multirow[t]{3}{*}{2 weeks } & $3-5 \mathrm{~cm}$ & 6,366 & $4,820 \mathrm{~b}$ & 4,435 & 15,622 b \\
\hline & $6-8 \mathrm{~cm}$ & 4,350 & $4,889 \mathrm{~b}$ & 3,820 & $13,059 \mathrm{~b}$ \\
\hline & Average & 5,358 & 4,855 & $4,128 b$ & 14,341 \\
\hline \multirow[t]{3}{*}{3 weeks } & $3-5 \mathrm{~cm}$ & 5,028 & 7,699 a & 6,628 & 19,355 a \\
\hline & $6-8 \mathrm{~cm}$ & 4,930 & 7,114 a & 6,967 & $19,011 \mathrm{a}$ \\
\hline & Average & 4,979 & 7,406 & 6,797 a & 19,183 \\
\hline \multirow[t]{3}{*}{4 weeks } & $3-5 \mathrm{~cm}$ & 6,799 & 7,844 a & 6,443 & 21,086 a \\
\hline & $6-8 \mathrm{~cm}$ & 3,797 & $5,382 b$ & 4,505 & $13,684 b$ \\
\hline & Average & 5,298 & 6,613 & $5,474 a b$ & 17,385 \\
\hline Average & $3-5 \mathrm{~cm}$ & 6,064 & 6,788 & 5,836 & 18,687 \\
\hline Intensity & $6-8 \mathrm{~cm}$ & 4,379 & 5,795 & 5,097 & 15,251 \\
\hline SEM & & 801.12 & 856.04 & 676.23 & $1,702.05$ \\
\hline Frequency & & NS & * & ** & * \\
\hline Intensity & & * & NS & NS & * \\
\hline Interaction & & NS & * & NS & * \\
\hline
\end{tabular}

$\boldsymbol{\Delta}=$ Frequencies of 4,5 and 6 weeks.

$\mathrm{SEM}=$ Standard error of the mean; NS= Not significant; ${ }^{*} P<0.01 ;{ }^{*} P<0.05$.

a,b Values with different superscript in columns indicate significant differences $(P<0.05$; Tukey). 
frecuencia de pastoreo (4 y 6 semanas en primavera-verano y otoño, respectivamente) en combinación con la mayor intensidad de pastoreo de 3 y $5 \mathrm{~cm}$ de altura del forraje residual (Cuadro 1). El pastoreo severo superó $(\mathrm{P}<0.05)$ en rendimiento de forraje al ligero en 38,17 y $14 \%$ en primavera, verano y otoño, respectivamente. La superioridad del pastoreo severo en cantidad de forraje encontrada en el presente estudio no coincide con otros estudios en donde el pastoreo severo y frecuente tiende a mostrar menor cantidad de forraje $(5,10,20)$. Dichas investigaciones concluyeron que los pastoreos frecuentes y severos reducen las reservas de carbohidratos, área foliar remanente, y como consecuencia la persistencia de la pradera. En el presente estudio el pasto ovillo demostró responder al pastoreo severo, siendo en el verano donde se registró su mayor ventaja en relación a la producción de forraje.

A la menor frecuencia (4 y 6 semanas) el pastoreo menos severo tendió a reducir la cantidad de forraje, pero en la frecuencia intermedia (3 y 5 semanas) la intensidad de pastoreo no promovió cambios en la cantidad de forraje. En la primavera y otoño, variar la frecuencia e intensidad de pastoreo no promovió cambios en la cantidad de forraje. Al respecto, se ha señalado $(21,22,23)$ que la mayor acumulación neta de forraje se registra cuando el dosel vegetal intercepta $95 \%$ de radiación solar, el cual varía de acuerdo a la estación del año y al manejo de la pradera. La mayor acumulación de forraje registrada en verano está directamente relacionada con la presencia de condiciones de humedad apropiadas y temperaturas óptimas, que permitieron un rápido crecimiento de las plantas $(3,4,9)$. La mayor frecuencia de pastoreo ( 2 y 4 semanas) mostró una tendencia a menor cantidad de forraje en otoño en comparación a primavera y verano, mientras que en las otras dos frecuencias esta tendencia no fue evidente; posiblemente el pastoreo frecuente dejó al ovillo más sensible a las condiciones climáticas adversas como heladas y baja temperatura del otoño $(3,4,9)$. to show less herbage yield $(5,10,20)$; these investigations have concluded that the frequent and hard grazing reduced carbohydrate reserves, residual leaf area, and as a result the sward persistence. In the present study, the Orchard grass respond to severe grazing, being in the summer where the biggest advantage of hard grazing on herbage yield were registered.

In the lowest frequency (4-6 wk) lax grazing tended to reduce herbage yield, but on the intermediate frequency (3-5 wk) the grazing intensity did not promote changes in the herbage yield. During spring and autumn, variation of the frequency and intensity of grazing did not promote changes in herbage yield. In this regard, it has been noted $(21,22,23)$ that the greatest net herbage accumulation is obtained when the plant canopy intercepts $95 \%$ of solar radiation, which varies according to the season of the year and to the pasture management. The greater herbage accumulation in summer is directly related to the presence of suitable moisture conditions and optimal temperatures, allowing rapid sward growth $(3,4,9)$. The increased grazing frequency ( 2 to $4 \mathrm{wk}$ ) showed a tendency to lower herbage yield in the fall compared to spring and summer, while in the two other frequencies, this trend was not evident; possibly the frequent grazing left the orchard grass more sensitive to adverse weather conditions such as frost and low autumn temperatures $(3,4,9)$.

The NHAR during summer and average of the three seasons was influenced $(P<0.05)$ by the grazing frequency and intensity and the interaction between both factors (Table 2). The tendency was to a lower NHAR with more frequent grazing ( 2 to $4 \mathrm{wk}$ ). The highest NHAR during summer and average were 107 and 91 kg DM ha-1 $\mathrm{d}^{-1}$, respectively, both obtained by the less frequent and more severe grazing sward every $4 \mathrm{wk}$ in summer and $3-5 \mathrm{~cm}$ of residual sward height. In the summer and seasonal average, only in the higher range frequency apply a less severe grazing (residual $6-8 \mathrm{~cm}$ ) caused a reduction in the NAHR of $68 \%$. 
La tasa de acumulación neta de forraje (TANF) del verano y promedio de las tres estaciones fue influida $(P<0.05)$ por la frecuencia e intensidad de pastoreo y por la interacción entre ambos factores (Cuadro 2). La tendencia fue a una menor TANF con el pastoreo más frecuente ( 2 y 4 semanas). Las máximas TANF para el verano y promedio fueron 107 y $91 \mathrm{~kg}^{\mathrm{MS}} \mathrm{ha}^{-1}$ $\mathrm{d}^{-1}$, respectivamente, ambas obtenidas por el pastoreo menos frecuente y más severo, pastoreo cada 4 semanas en verano y $3-5 \mathrm{~cm}$ de forraje residual. En el verano y promedio estacional, solamente en la frecuencia de mayor intervalo aplicar un pastoreo menos severo (residual de 6-8 cm) ocasionó una reducción en la TANF de $68 \%$. Las variaciones entre estaciones de la TANF están relacionadas con el manejo del pastoreo y con la estacionalidad de crecimiento del pasto y las condiciones climatológicas, como se ha observado en
Variations between seasons in the NHAR are related with the grazing management and the seasonality of grass growth and weather conditions, as it has been observed in studies with perennial ryegrass $(10,21,23)$ and orchard grass(3). In autumn and spring the overall average NHAR was the least, with approximately $60 \mathrm{~kg} \mathrm{DM} \mathrm{ha}^{-1} \mathrm{~d}^{-1}$, similar to the one registered in other studies(24) and value explained based on reductions in ambient temperature and photoperiod.

In relation to the NHAR average observed by grazing at 4-6 wk during the entire period of study, some authors $(25,26,27)$ indicated that as the frequency of defoliation increases, more opportunity to the pasture for accumulating a greater leaf area, allowing more interception of solar radiation and net photosynthesis, resulting at the end in a higher dry matter yield.

Cuadro 2. Tasa de acumulación neta de forraje estacional y promedio (kg MS ha-1 $\left.\mathrm{d}^{-1}\right)$ de pasto ovillo, en respuesta a tres frecuencias y dos intensidades de pastoreo

Table 2. Seasonal net herbage accumulation rate $\left(\mathrm{kg} \mathrm{DM} \mathrm{ha}^{-1} \mathrm{~d}^{-1}\right)$ of orchard grass, in response to three frequencies and two grazing intensities

\begin{tabular}{|c|c|c|c|c|c|}
\hline \multicolumn{2}{|c|}{ Treatments } & \multicolumn{3}{|c|}{ Season } & \multirow[b]{2}{*}{ Average } \\
\hline Frequency & Intensity & Spring & Summer & $\overline{\text { Fall } \Delta}$ & \\
\hline 2 weeks & $\begin{array}{c}3-5 \mathrm{~cm} \\
6-8 \mathrm{~cm} \\
\text { Average }\end{array}$ & $\begin{array}{l}76 \\
52 \\
64\end{array}$ & $\begin{array}{l}57 \mathrm{~b} \\
58 \mathrm{~b} \\
58\end{array}$ & $\begin{array}{l}53 \\
45 \\
49\end{array}$ & $\begin{array}{l}62 \mathrm{~b} \\
52 \mathrm{~b} \\
57\end{array}$ \\
\hline 3 weeks & $\begin{array}{c}3-5 \mathrm{~cm} \\
6-8 \mathrm{~cm} \\
\text { Average }\end{array}$ & $\begin{array}{l}60 \\
59 \\
59\end{array}$ & $\begin{array}{l}92 a \\
85 a b \\
88\end{array}$ & $\begin{array}{l}63 \\
66 \\
65\end{array}$ & $\begin{array}{l}72 a b \\
70 a b \\
71\end{array}$ \\
\hline 4 weeks & $\begin{array}{c}3-5 \mathrm{~cm} \\
6-8 \mathrm{~cm} \\
\text { Average }\end{array}$ & $\begin{array}{l}90 \\
45 \\
68\end{array}$ & $\begin{array}{r}107 \mathrm{a} \\
64 \mathrm{~b} \\
85\end{array}$ & $\begin{array}{l}77 \\
54 \\
65\end{array}$ & $\begin{array}{l}91 \mathrm{a} \\
54 \mathrm{~b} \\
73\end{array}$ \\
\hline $\begin{array}{l}\text { Average } \\
\text { intensity }\end{array}$ & $\begin{array}{l}3-5 \mathrm{~cm} \\
6-8 \mathrm{~cm}\end{array}$ & $\begin{array}{l}75 \\
52\end{array}$ & $\begin{array}{l}85 \\
69\end{array}$ & $\begin{array}{l}64 \\
55\end{array}$ & $\begin{array}{l}75 \\
59\end{array}$ \\
\hline SEM & & 9.88 & 10.12 & 7.87 & 6.80 \\
\hline Frequency & & NS & ** & NS & * \\
\hline Intensity & & * & * & NS & ** \\
\hline Interaction & & NS & $* *$ & NS & $* *$ \\
\hline
\end{tabular}

$\boldsymbol{\Delta}=$ Frequencies of 4,5 and 6 weeks.

$\mathrm{SEM}=$ Standard error of the mean; NS= Not significant; ${ }^{* *} P<0.01 ;{ }^{*} P<0.05$.

$a, b$ Values with different superscript in columns indicate differences $(P<0.05$; Tukey). 
estudios realizados con ballico perenne $(10,21,23)$ y pasto ovillo(3). En el otoño y en primavera el promedio general de la TANF fue el menor con aproximadamente $60 \mathrm{~kg}$ MS ha-1 $\mathrm{d}^{-1}$, valor similar al registrado en otros estudios(24) y explicado con base a reducciones en la temperatura ambiental y fotoperiodo.

En relación a la mayor promedio de TANF observada al pastorear a 4 y 6 semanas durante todo el periodo de estudio, algunos autores $(25,26,27)$ indicaron que conforme se incrementa el intervalo de defoliación, se da la oportunidad a la pradera de acumular una mayor área foliar, permitiendo mayor intercepción de la radiación solar y fotosíntesis neta, dando como resultado final mayor rendimiento de materia seca.

Aplicar pastoreo ligero (6 a $8 \mathrm{~cm}$ de residual) ocasionó una TANF menor en 23 a $44 \%$ con respecto de la TANF del pastoreo severo, excepto en el otoño, donde no se registró efecto $(P>0.05)$ de la intensidad del pastoreo. Después de una defoliación, la proporción de luz interceptada por el tejido foliar antes de alcanzar el suelo, aumenta progresivamente conforme lo hace el área foliar por unidad de superficie, hasta alcanzar un índice de área foliar (IAF) óptimo, donde la tasa de asimilación neta de carbono es máxima y declina con incrementos adicionales en el $\mathrm{IAF}^{(4)}$. Sin embargo, la efectividad en la intercepción y transformación de la energía solar recibida dependerá de la capacidad fotosintética del tejido foliar residual(26).

En la Figura 2 se muestra la variación estacional, de los componentes morfológicos y su contribución en porcentaje, al rendimiento de forraje. Independientemente de la frecuencia e intensidad de pastoreo, durante primavera y verano la contribución de hoja al rendimiento de forraje fue superior a $80 \%$. El aporte de hoja fue mayor y el de tallo y material muerto menor en el pastoreo ligero en comparación al severo. Esta tendencia coincide con lo registrado en otros estudios $(3,24,27)$ que durante la
By Applying lax grazing (6-8 $\mathrm{cm}$ of residual) caused NHAR lower in 23 to $44 \%$ with respect to the hard grazing, except in the fall, where there was no effect $(P>0.05)$. After a defoliation, the proportion of light intercepted by foliar tissue before reaching the ground, increases progressively as it does the leaf area per unit area, until reach an optimal leaf area index (LAl), where net carbon assimilation rate is maximum and declines with additional LAl increases(4). However, the effectiveness in the interception and transformation of the solar energy received will depend on the photosynthetic capacity of the residual foliar tissue(26).

Figure 2 shows the seasonal variation of morphological components and their contribution as a percentage of the herbage yield. Regardless of the frequency and intensity of grazing, during spring and summer, the contribution of leaf to herbage yield was greater than $80 \%$. The contribution of leaf was higher and stem and dead material lower in lax grazing compared to the hard. This trend coincides with other studies $(3,24,27)$ where during the spring and summer, lax grazing presented higher leaves percentage and lower stem and dead material than hard grazing. Some studies $(4,24,27)$ attributed this trend to the higher proportion of stem and dead material in the lower layers.

In autumn, the highest values of dead material on all treatments obtained were higher, up to $100 \%$ in some cases vs spring and summer (Figure 2). Also observed a gradual increase in the contribution of dead material as the grazing interval was greater. With respect to frequencies, lax grazing recorded a higher percentage of dead material and lower proportion of stems than the hard grazing. The presence of frost, associated with low temperatures (around 0 ${ }^{\circ} \mathrm{C}$ ) recorded in mid-to-late autumn, could contribute to the death of leaves of the upper layers, particularly in plants harvested more lightly. Another factor that might contribute to the high presence of dead material was the 
primavera y verano, el pastoreo ligero presentó mayor porcentaje de hojas y menor de tallos y material muerto que el pastoreo severo. Algunos estudios $(4,24,27)$ atribuyeron esta tendencia a que en los estratos inferiores se encuentra una mayor proporción de tallo y material muerto.

En el otoño se obtuvieron los mayores valores de material muerto en todos los tratamientos y fueron hasta $100 \%$ superiores en algunos casos, con respecto a los registrados en primavera y verano (Figura 2). También se observó un incremento progresivo en el aporte de material muerto conforme el intervalo entre pastoreos fue mayor. Respecto a las intensidades, el pastoreo ligero registró mayor porcentaje de material muerto y menor proporción de tallos que el pastoreo severo. La presencia de heladas, asociadas con las bajas temperaturas (alrededor de 0o C) que se registraron a mediados y finales de otoño, pudieron contribuir a la muerte de hojas de los estratos superiores, particularmente en las plantas cosechadas más ligeramente. Otro factor que pudo contribuir a la alta presencia de material muerto, fue el incremento, de dos semanas, en los intervalos de pastoreo en todos los tratamientos, los cuales permitieron el aumento en el porcentaje de hojas maduras y senescentes.

Al evaluar la contribución de los componentes morfológicos al rendimiento, durante un ciclo de crecimiento de ocho semanas en las diferentes estaciones del año, estudios(3) reportaron un aumento progresivo en la acumulación de tallo y material muerto conforme se incrementaba la edad de rebrote, similar al observado en el presente estudio durante el otoño en las frecuencias de 4,5 y 6 semanas. Al respecto, algunos autores(27) señalan que una vez que la planta intercepta el $95 \%$ de la radiación solar, hay un incremento progresivo en el material senescente y muerto, debido al sombreado de las hojas presentes en los estratos inferiores del dosel vegetal, lo cual pudo ocurrir con los intervalos de pastoreo más prolongados (Figura 2).
Figura 2. Composición morfológica de pasto ovillo, en respuesta a tres frecuencias y dos intensidades de pastoreo

Figura 2. Morphological components of orchard grass in response to three frecuencies and two intensities

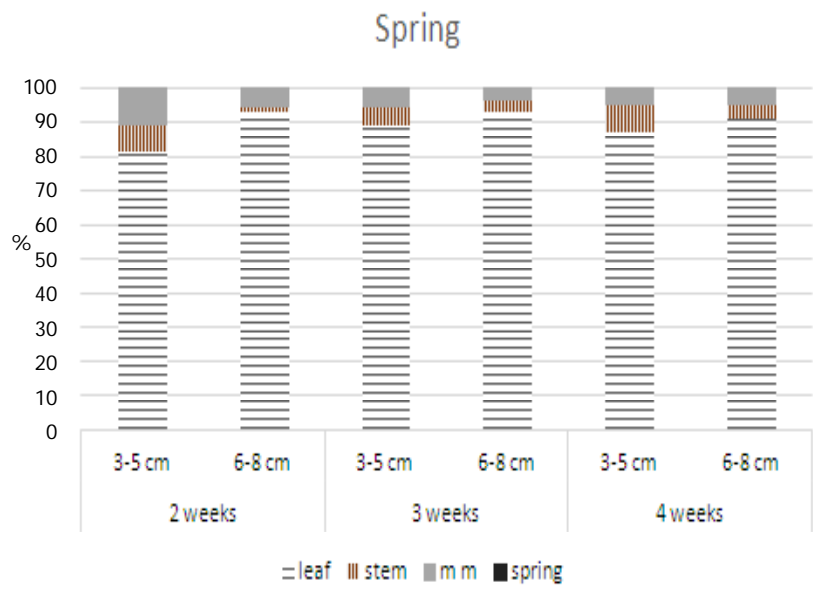

Summer

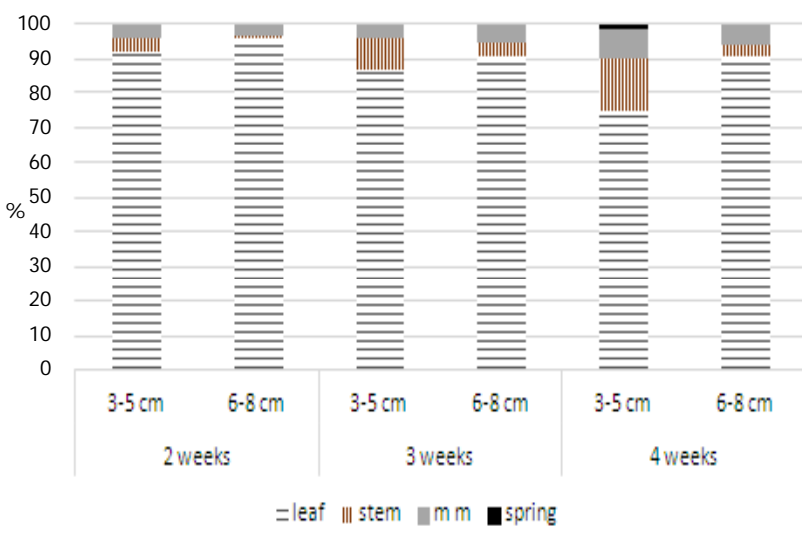

Fall

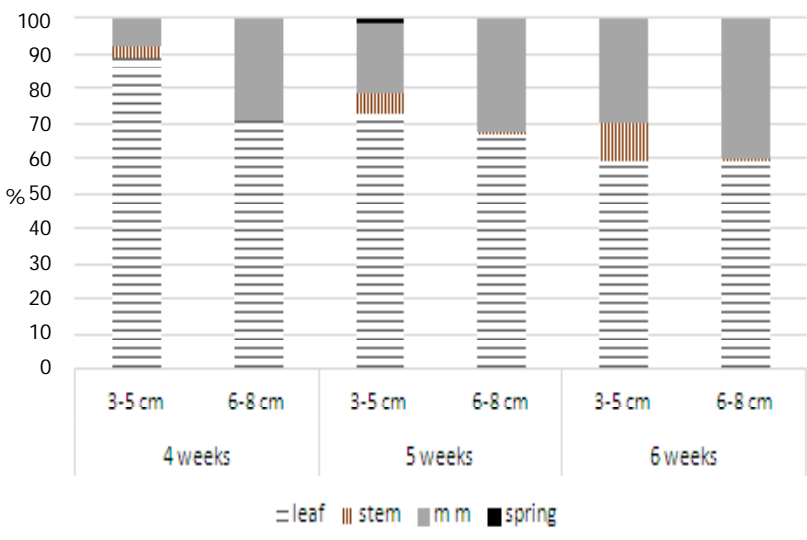


No se presentó efecto de interacción entre frecuencia e intensidad de pastoreo durante todo el periodo de estudio en los cambios estacionales del contenido de proteína total (Cuadro 3). Durante primavera, otoño y en el promedio estacional, se observaron efectos de frecuencia de pastoreo $(P<0.05)$. En general, el contenido de proteína total, tendió a disminuir conforme aumentó el intervalo de pastoreo, siendo esta disminución más marcada durante el otoño (14 unidades porcentuales, al pastorear cada 4 y 6 semanas). Tal reducción pudo estar asociada con el mayor porcentaje de material muerto registrado en la frecuencia de 6 semanas (Figura 2). Durante el verano hubo un comportamiento similar, sin ser estadísticamente significativo; pastoreos cada 2 y 3 semanas promovieron valores iguales (22 \%), pero increase of 2 wk, at grazing intervals in all treatments, which allowed the increase in the percentage of mature leaves and senescence.

By evaluating the contribution of morphological components to the herbage yield during a 8-wk growth cycle in the different seasons of the year, studies reported(3) a progressing increase in the stem accumulation and dead material as the regrowth age was increased. Similar trend was observed in the present study during the autumn in the 4, 5 and 6 wk frequencies. Some authors (27) point out that once the plant intercepts $95 \%$ of solar radiation, have a progressive increase in the senescent and dead material due to shading of the leaves in the lower layers of the plant canopy, which might occur with the longer grazing intervals (Figure 2).

Cuadro 3. Cambios estacionales en el contenido de proteína total (PROT) y digestibilidad in vitro de la materia seca (IVDDM) del pasto ovillo, en respuesta a tres frecuencias y dos intensidades de pastoreo

Table 3. Seasonal changes in total protein content (PROT) and in vitro dry matter digestibility (IVDMD) of orchard grass in response to three frequencies and two grazing intensities

\begin{tabular}{|c|c|c|c|c|c|c|c|c|c|}
\hline \multicolumn{2}{|c|}{ Treatments } & \multicolumn{2}{|c|}{ Spring } & \multicolumn{2}{|c|}{ Summer } & \multicolumn{2}{|c|}{ Fall $\Delta$} & \multicolumn{2}{|c|}{ Average } \\
\hline Frequency & $\overline{\text { Intensity }}$ & $\begin{array}{c}\text { PROT } \\
(\%)\end{array}$ & IVDDM & $\begin{array}{c}\text { PROT } \\
(\%)\end{array}$ & IVDDM & $\begin{array}{c}\text { PROT } \\
(\%)\end{array}$ & IVDDM & $\begin{array}{c}\text { PROT } \\
(\%)\end{array}$ & IVDDM \\
\hline 2 weeks & $\begin{array}{c}3-5 \mathrm{~cm} \\
6-8 \mathrm{~cm} \\
\text { Average }\end{array}$ & $\begin{array}{l}22 \\
25 \\
23 a\end{array}$ & $\begin{array}{l}61 \\
70 \\
66\end{array}$ & $\begin{array}{l}22 \\
22 \\
22\end{array}$ & $\begin{array}{l}68 \\
70 \\
69 a\end{array}$ & $\begin{array}{l}23 \\
19 \\
21 \mathrm{a}\end{array}$ & $\begin{array}{l}70 \\
62 \\
66\end{array}$ & $\begin{array}{l}22 \\
22 \\
22 \text { a }\end{array}$ & $\begin{array}{l}67 \\
67 \\
67 \text { a }\end{array}$ \\
\hline 3 weeks & $\begin{array}{c}3-5 \mathrm{~cm} \\
6-8 \mathrm{~cm} \\
\text { Average }\end{array}$ & $\begin{array}{l}21 \\
23 \\
22 a b\end{array}$ & $\begin{array}{l}65 \\
67 \\
66\end{array}$ & $\begin{array}{l}22 \\
22 \\
22\end{array}$ & $\begin{array}{l}74 \\
70 \\
72 \text { a }\end{array}$ & $\begin{array}{l}18 \\
16 \\
17 b\end{array}$ & $\begin{array}{l}67 \\
57 \\
62 a\end{array}$ & $\begin{array}{l}20 \\
20 \\
20 \text { a }\end{array}$ & $\begin{array}{l}69 \\
65 \\
67 \text { a }\end{array}$ \\
\hline 4 weeks & $\begin{array}{c}3-5 \mathrm{~cm} \\
6-8 \mathrm{~cm} \\
\text { Average }\end{array}$ & $\begin{array}{l}17 \\
22 \\
20 b\end{array}$ & $\begin{array}{l}63 \\
63 \\
63\end{array}$ & $\begin{array}{l}15 \\
19 \\
17\end{array}$ & $\begin{array}{l}63 \\
67 \\
65 b\end{array}$ & $\begin{array}{l}15 \\
15 \\
15 b\end{array}$ & $\begin{array}{l}54 \\
50 \\
52 \text { b }\end{array}$ & $\begin{array}{l}16 \\
19 \\
17 \text { b }\end{array}$ & $\begin{array}{l}60 \\
60 \\
60 \mathrm{~b}\end{array}$ \\
\hline $\begin{array}{l}\text { Average } \\
\text { intensity }\end{array}$ & $\begin{array}{l}3-5 \mathrm{~cm} \\
6-8 \mathrm{~cm}\end{array}$ & $\begin{array}{l}20 \\
23\end{array}$ & $\begin{array}{l}63 \\
67\end{array}$ & $\begin{array}{l}20 \\
21\end{array}$ & $\begin{array}{l}68 \\
69\end{array}$ & $\begin{array}{l}19 \\
17\end{array}$ & $\begin{array}{l}64 \\
56\end{array}$ & $\begin{array}{l}19 \\
20\end{array}$ & $\begin{array}{l}65 \\
64\end{array}$ \\
\hline SEM & & 1.11 & 2.71 & 2.03 & 2.38 & 0.97 & 1.61 & 1.04 & 2.1 \\
\hline Frequency & & * & NS & NS & * & ** & ** & ** & ** \\
\hline Intensity & & ** & NS & NS & NS & * & ** & NS & NS \\
\hline Interaction & & NS & NS & NS & NS & NS & NS & NS & NS \\
\hline
\end{tabular}

$\boldsymbol{\Delta}=$ Frequencies of 4,5 and 6 weeks.

$\mathrm{SEM}=$ Standard error of the mean; NS= Not significant; ${ }^{* *} P<0.01 ;{ }^{*} P<0.05$;

a,b Values with different superscript in columns, indicate differences $(P<0.05$; Tukey). 
mayores a los de 4 semanas (17 \%). Una tendencia similar se observó en otra investigación(28), en un análisis de crecimiento de pasto ovillo durante un ciclo de 59 días, en donde los niveles de proteína disminuyeron conforme avanzó la edad del rebrote de 14 a 47 y 59 días $\left(11>8>6 \mathrm{mg} \mathrm{g}^{-1}\right.$ tejido, respectivamente). En ballico perenne(25), también se han obtenido resultados similares al registrado en este estudio, una disminución en el contenido de proteína al aumentar el intervalo de defoliación de 2 a 4 y 6 semanas, por lo que concluyeron que la proporción de proteína fue mayor en los rebrotes más jóvenes, que resultan con cortes más frecuentes.

Sólo se registraron efectos significativos de intensidad de pastoreo en primavera y otoño $(\mathrm{P}<0.05)$. Durante primavera los pastoreos más ligeros superaron al severo ( 23 vs $20 \%$ ). Caso contrario ocurrió en el otoño, en donde el pastoreo severo superó al ligero 2 unidades porcentuales ( 19 vs $17 \%$ ). Tal comportamiento pudo estar asociado con el porcentaje de hojas y material muerto, registrados en ambas estaciones (Figura 2). En primavera, el contenido de hojas con el pastoreo ligero fue superior al $90 \%$, con una mínima participación del tallo y material muerto; mientras que en otoño, sucedió lo contrario, el pastoreo severo presentó una mayor proporción de hojas y tallos, y menor cantidad de material muerto que el ligero, lo cual afectó positivamente el contenido de proteína total, como ha sido señalado por varios autores $(4,20)$.

El mayor contenido de proteína total observado en este estudio ocurrió durante la primavera con el pastoreo ligero, esto pudo estar relacionado con la metodología usada para colectar el material vegetal, en la cual se simuló la dieta que los animales estaban consumiendo(29), por lo que se cosechó una mayor proporción de hoja y una menor cantidad de tallo y material muerto que con el pastoreo severo $(4,27,30)$. La composición morfológica del pasto ovillo también varió con la distribución vertical, con el menor porcentaje de hoja en el estrato inferior, e
There was not an effect of interaction between grazing frequency and grazing intensity during the entire period of study on the seasonal changes of the total protein contents (Table 3). In spring, autumn and on the seasonal average, grazing frequency effects were observed $(P<0.05)$. In general, the contents of total protein, tended to decline as grazing frequency increased, being this decrease most marked during autumn (14 percentage units for grazing every 4-6 wk). Such a reduction could be associated with the highest percentage of dead material recorded in the 6-wk frequency (Figure 2). During the summer, there was a similar trend, but not significant $(P>0.05)$; grazing every 2-3 wk promoted equal values (22\%), but higher than the 4-wk (17\%). A similar trend was observed in another study(28), in an analysis of orchard grass growth during a 59-d cycle; protein levels decreased as regrowth age rose from 14 to 47 and $59 \mathrm{~d}$ ( $11>8>6 \mathrm{mg}$ $\mathrm{g}^{-1}$ tissue-1, respectively). In perennial ryegrass(25), similar results were also obtained; a decrease in the protein content by increasing the defoliation frequency from 2 to $4-6 \mathrm{wk}$, and they concluded that the proportion of protein was higher in the younger regrowth, as a result of more frequent cuts.

Only significant effects of grazing intensity were recorded in spring and autumn $(\mathrm{P}<0.05)$. During spring, the lax grazing outperformed the hard (23 vs $20 \%$ ). Otherwise occurred in the autumn, where hard grazing outperformed the lax by 2 percentage units ( 19 vs $17 \%$ ). Such performance could be associated to the percentage of leaves and dead material, recorded in both seasons (Figure 2). In spring, the leaves with lax grazing content was greater than $90 \%$, with a minimum participation of the stem and dead material. While in autumn, it happened otherwise, hard grazing presented a higher proportion of leaves and stems, and fewer dead material than the lax one, which positively affected the contents of total protein, as it has been pointed out by several authors(4.20). 
incrementando progresivamente hacia los estratos superiores, y lo opuesto ocurre con el tallo y el material muerto(4).

No se presentó efecto de interacción frecuencia $x$ intensidad de pastoreo, durante todo el periodo de evaluación en la digestibilidad in vitro de la materia seca (DIVMS) (Cuadro 3). Sólo se registraron efectos de frecuencia de pastoreo en verano, otoño y en el promedio estacional $(P<0.05)$. En general, los intervalos de pastoreo de 2 y 3 semanas mostraron valores de DIVMS similares entre ellos, siendo superiores a los de 4 y 6 semanas $(P<0.05)$. El valor nutritivo de los forrajes, disminuye al avanzar la madurez y el material muerto constituye la fracción menos digestible, por lo que los intervalos cortos, proporcionan un forraje de alta digestibilidad, en comparación con los intervalos prolongados de crecimiento $(4,20)$. Respecto a la intensidad de pastoreo, sólo se observó efecto significativo durante el otoño $(P<0.05)$, siendo el pastoreo severo el que registró la mayor DIVMS (64 vs $56 \%$ ). Esto puede atribuirse a la mayor proporción de hoja verde y menor porcentaje de material muerto presente en los pastoreos más severos (Figura $2)$. Algunos autores $(12,20,25)$ han señalado que la hoja verde es más digestible que el material muerto, y durante el otoño existió una mayor aportación de este material al rendimiento de forraje.

Se concluye que para obtener un mayor rendimiento de forraje, el manejo del pastoreo debe variar de acuerdo con la estación de año. En primavera y verano el pasto ovillo debe pastorearse a intervalos de 4 semanas, en tanto que durante el otoño la frecuencia debe ser de 5 semanas. Pastoreos a una intensidad severa estimula el rendimiento de forraje. Pastoreos a intervalos mayores a 5 semanas a una intensidad ligera, estimulan la presencia de material muerto y reducen la calidad del forraje. Tanto el contenido de proteína, como el porcentaje de DIVMS disminuyeron al aumentar el intervalo de pastoreo.
The higher total protein content observed in this study took place during the spring with lax grazing. This could be related to the methodology used to collect plant material, which simulated the diet that the animals were eating(29), by what was harvested a greater proportion of leaf and a lesser amount of stem and dead material that with hard grazing $(4,27,30)$. The morphological composition of the orchard grass also varied with the vertical distribution, with the lowest leaf percentage in the bottom stratum, and gradually increasing towards the upper layers; and the opposite happens with the stem and dead material(4).

There was not effect of frequency $x$ grazing intensity interaction during the entire evaluation period for the in vitro dry matter digestibility (IVDMD) (Table 3). Only grazing frequency effects were significant in summer, autumn and on the seasonal average $(\mathrm{P}<0.05)$. In general, grazing of 2 and 3 wk intervals showed similar IVDMD values between them, being higher than for 4 and 6 wk $(P<0.05)$. The herbages nutritive value, decreases as maturity advance and dead material constitutes the less digestible fraction, so the short intervals provide a high digestibility herbage, in comparison with the long growth intervals(4.20). With respect to grazing intensity, only fall was significant $(P<0.05)$, being hard grazing which recorded the largest IVDMD (64 vs $56 \%$ ). This can be attributed to the higher proportion of green leaves and lower dead material percentage present in the most severe grazing (Figure 2 ). Some authors $(12,20,25)$ have pointed out that the green leaf is more digestible than the dead material and, during the autumn there was a greater input of this material to herbage yield.

In conclusion, to obtain a higher herbage yield, grazing management should vary according to the season of the year. In spring and summer, the orchard grass swards should be grazing at 4-wk intervals, whereas during the autumn the frequency must be $5 \mathrm{wk}$. Grazing at a hard intensity stimulates herbage yield. Grazing at intervals greater than 5 wk at a lax intensity 


\section{AGRADECIMIENTOS}

A CONACYT por el financiamiento otorgado para la realización de los estudios de maestría del primer autor. Los autores agradecen a la Línea Prioritaria de Investigación 11: Sistemas de Producción Agrícola, Pecuaria, Forestal, Acuícola y Pesquera por el financiamiento parcial otorgado para la realización del presente estudio.

\section{LITERATURA CITADA}

1. Da Silva SC, Hernández-Garay A. Manejo del pastoreo en praderas tropicales. En: Velazco ZME et al. editores. Los forrajes y su impacto en el trópico. 1ra. ed. Chiapas, México: Universidad Autónoma de Chiapas; 2010:63-95.

2. Hannaway D, Fransen S, Cropper J, Teel M, Chaney M, Griggs T, et al. Orchard Grass. Oregon. USA: Oregon State University; 1999;502.

3. Velasco-Zebadúa ME, Hernández-Garay A, GonzálezHernández VA, Pérez-Pérez J, Vaquera-Huerta H, Galvis SA. Curva de crecimiento y acumulación estacional del pasto ovillo (Dactilysglomerata L.). Téc Pecu Méx 2001;39:1-14.

4. Hodgson J. Grazing management: Science into practice. 1rst ed. Harlow, England: Longman Scientific Technical; 1990; 203.

5. Fagundes J L, Da Silva SC, Pedreira CGS, Carnevalli RA, Carvalho CAB, Sbrissia, AF, Pinto LFM. Intensidades de pastejo e a composição morfológica de pastos de Cynodon spp. Sci Agric 1999;56:897-908.

6. Fulkerson WJ, Donaghy DJ. Plant soluble carbohydrate reserves and senescence-key criteria for developing an effective grazing management system for ryegrass-based pastures: a review. Aust J Exp Agric 2001;41:261-275.

7. Turner LR, Donaghy DJ, Lane PA, Rawnsley RP. Effect of defoliation interval on water-soluble carbohydrate and nitrogen reserves, regrowth of leaves and roots, and tiller number of cockfoot (DactylisglomerataL.) plants. Aust J Agric Res 2006; 57:243-249.

8. Donaghy $D J$, Fulkerson WJ. Priority for allocation of watersoluble carbohydrate reserves during regrowth of Luliumperenne. Grass Forage Sci 1998;53:211-218.

9. DonaghyDJ, Turner LR, Adamczewski KA. Effect of defoliation management on water-soluble carbohydrate energy reserves, dry matter yields, and herbage quality of tall fescue. Agron J 2008; 100: 122-127.

10. Garduño VS, Pérez PJ, Hernández GA, Herrera HJ G, Martínez HPA, J oaquín, TBM. Rendimiento y dinámica de crecimiento estacional de ballico perenne, pastoreado con ovinos a diferentes frecuencias e intensidades. Téc Pecu Méx 2009; 47(2): 189-202.

11. Carlen C, Kölliker J, Reidy B, Lüscher A, Nösberger J. Effect of season and cutting frequency on root and shoot competition between Festucapratensis and Dactylisglomerata. Grass Forage Sci 2002; 57:247-254. stimulates the presence of dead material, and reduces herbage quality. Both protein content and IVDDM percentage declined when grazing frequency increase.

\section{ACKNOWLEDGMENTS}

To CONACYT for the funding granted to the Master's studies of the first author. The authors are grateful to the priority Research 11: "Systems of production agriculture, livestock, forestry, aquaculture, and fisheries" by the partial financing for the realization of this study.

End of english version

12. Ducrocq $H$, Duru M. In vitro digestibility of green lamina of cocksfoot (Dactylisglomerata L.) in relation to water deficit. Grass Forage Sci 1997;52:432-438.

13. Turner LR, Donaghy DJ, Lane PA, Rawley RP. Effect of defoliation management, based on leaf stage, on perennial ryegrass (Loliumperenne L.), prairie grass (BromuswilldenowiiKunth.) and cocksfoot (Dactylisglomerata L) under dry land conditions. 1. Regrowth, tillering and water-soluble carbohydrate concentration. Grass Forage Sci 2006;61:164-174.

14. Rawley RP, Donaghy DJ, Fulkenson WJ, Lane PA. Changes in the physiology and feed quality of cocksfoot (Dactylisglomerata L.) during regrowth. Grass Forage Sci 2002; 57:203-211.

15. García E. Modificaciones al sistema de clasificación climática de Köppen. 4a.ed. D.F, México: Universidad Nacional Autónoma de México; 1988.

16. Ortiz SC. Colección de monolitos. Génesis de suelos. Montecillo, Texcoco, Estado de México, México: Edafología, IRENAT. Colegio de Posgraduados; 1997.

17. Association of Official Analytical Chemists (AOAC). Official Methods of Analysis 14th ed. Arlington. Va. USA: Association of Official Analytical Chemists; 1984.

18. Tiller JMA, Terry RA. A two stage technique for the in vitro digestion of forage crops. J Brit Grassl Soc 1963;18:104-111.

19. SAS. SAS. User's guide: Statistics (version 8ed). Cary, NC, USA: SAS Inst. Inc. 2009.

20. Hodgson J, Brookes IM. Nutrition of grazing animals. In: New Zealand Pasture and Crop science. Auckland, New Zealand: Oxford University Press; 1999;323.

21. Wilman W. The effect of grazing compared with cutting different frequencies on a lucerne-cockfoot. J Agric Sci 1977; 88(3): 483-492.

22. Spandl E, Hesterman OB. Forage quality and alfalfa characteristics in binary mixtures of alfalfa and bromegrass or timothy. Crop Sci 1997;37:1581-1585. 
23. Velasco-Zebadúa ME, Hernández-Garay A, GonzálezHernández VA, Pérez-Pérez J, Vaquera-Huerta H. Curvas estacionales de crecimiento del ballico perenne. Rev Fitot Méx 2002;25:97-107.

24. Zaragoza EJA, Hernández-Garay A, Pérez PJ, Herrera HJG, Osnaya GF, Martínez HPA, González, MSS, Quero CAR. Análisis de crecimiento estacional de una pradera asociada alfalfa- pasto ovillo. Téc Pecu Méx 2009;47(2):173-188.

25. Velasco-Zebadúa ME, Hernández-Garay A, GonzálezHernández VA. Rendimiento y calidad del ballico perenne (Lolium perenne L.) en respuesta a la frecuencia de corte. Téc Pecu Méx 2005;43(2):247-258.

26. Grant SA, Barthram GT, Torvell L. Components of regrowth in grazed and cut Loliumperenne swards. Grass Forage Sci 1981; 36: 155-168.
27. Chapman DF, Lemaire G. Morphogenetic and structural determinants of plant regrowth after defoliation. Proc. XVII Inter Grassland Cong. Palmerston North, New Zealand. 1993: 95-104.

28. Wilson-García CY, Zavaleta-Mancera HA, López-Delgado H, Hernández-Garay A. La citocinina BAP retrasa senescencia aumentando antioxidantes, proteína y crecimiento en pasto ovillo. Agrociencia 2008;42(7):799-806.

29. Sollenberger LE, Cherney DJR. Evaluating forage production and quality. The Science Grassland Agriculture. Ames: Iowa State University Press; 1995:97-110.

30. Acosta G, Ayala A, Acosta A. Comportamiento en pastoreo de ganado lechero sobre una pastura graminosa de Dactylisglomerata L. pastoreada en distintas edades de rebrote. Rev Arg Prod Anim 2006;26:23-30. 
